\title{
Genetic Evaluations of Dairy Bulls for Daughter Energy Balance Profiles Using Linear Type Scores and Body Condition Score Analyzed Using Random Regression
}

\author{
M. P. Coffey, ${ }^{*}$ G. Simm, ${ }^{*}$ W. G. Hill, $†$ and S. Brotherstone $†$ \\ *Animal Biology Division, Scottish Agricultural College, \\ West Mains Road, Edinburgh EH9 3JG, UK \\ †Institute of Cell, Animal and Population Biology, University of Edinburgh, \\ West Mains Road, Edinburgh, EH9 3JT, UK
}

\section{ABSTRACT}

The difference in body lipid between the start and end of lactation represents the body energy lost (or gained) in support of maintaining lactation including the nonproduction components of lactation. This source of energy is ignored in current genetic evaluations for production for dairy sires. The depletion and accretion of body tissue creates a pattern of body energy content over time that is, in part, under genetic control. Using random regression and field data, we modeled changes in body condition score (BCS) and liveweight, predicted from linear type traits, on first parity cows to produce daily breeding values of their sires for energy balance. These curves show that sires differ in the way their daughters lose and regain body energy throughout lactation. For all sires, the overall mean maximum daughter body energy loss was $1499 \mathrm{MJ}(\mathrm{SD}=144 \mathrm{MJ})$ and occurred at d $99(\mathrm{SD}=12.8 \mathrm{~d})$ of lactation and the mean total daughter body energy loss at d 305 of lactation was $779 \mathrm{MJ}(\mathrm{SD}=224 \mathrm{MJ})$. In this study, the profiles of body energy loss indicate that daughters of most sires lost body energy before $d 150$ and then recovered body energy, whereas the daughters of a few sires continued to lose body energy through to the end of lactation. Some sires with high merit for production may have daughters with body tissue mobilization profiles associated with poorer health and fertility leading to higher costs. A method of accounting for this cost could be to correct yield for body tissue mobilization. Deducting kilograms of milk from the breeding value for milk for each sire, equivalent in energy content to the body energy lost, resulted in a correlation of 0.98 between the ranking of sires for milk kilograms before and after adjustment. However, some sires changed rank by large amounts, the largest being +355 positions. Breeding

Received September 23, 2002.

Accepted January 13, 2003.

Corresponding author: M. P. Coffey; e-mail: m.coffey@ed.sac.ac.uk. values for energy balance can be calculated from single observations of BCS and linear type traits on daughters of a sire; data that can routinely be collected in national conformation assessment schemes.

(Key words: dairy bull, energy balance, genetics, selection)

Abbreviation key: conW = conceptus weight, HUK $=$ Holstein UK, LWT = liveweight, $\mathbf{P I N}=$ profit index .

\section{INTRODUCTION}

Body lipids are used by lactating mammals as a temporary energy buffer when daily energy requirements exceed daily energy availability (Pond and Newsholme, 1999). This is particularly pronounced in early lactation, when feed energy intake usually lags behind milk energy output, creating what is referred to as negative energy balance. In lactating dairy cattle, some or all of the lost body energy is replenished later in lactation. Therefore, the use of body lipids in support of lactation is cyclical, corresponding to the lactation and pregnancy cycles, which creates a pattern of changing body energy content over time.

BCS is a technique of appraising the fat content of the body using visual and tactile methods (Lowman et al., 1976). There is a good relationship between BCS and total body fat content (Fox et al., 1999) such that BCS is a useful management aid for dairy farmers in monitoring the nutritional and metabolic status of cows. Furthermore, BCS levels and changes in BCS are associated with the health and fertility status of the cow (Veerkamp et al., 2000; De Vries et al., 2000; Collard et al., 2000; Pryce et al., 2001), so BCS is an obvious target for potential selection indices. Selection for yield alone has resulted in cows that have a lower BCS than cows of average genetic merit for production (Pryce et al., 1999). Using random regression techniques of analysis on field data with BCS measured at different times but only once on each animal, Jones et al. (1999) demonstrated that changes in BCS throughout lactation are 
under genetic control and that BCS has a heritability of around 0.3. De Vries et al. (1999) reported a similar analysis with data from the Netherlands. Coffey et al. (2001), using data from an experimental herd, showed that BCS and liveweight (LWT) could be combined into an overall genetic energy balance curve for sires based on measurements of their daughters. If energy balance curves can be calculated for sires using field data collected from their daughters, the opportunity arises to explore the genetic relationship between these curves and health, fertility, and survival traits. BCS is relatively easy and cheap to measure on large numbers of daughters via progeny testing and national conformation assessment schemes. Energy balance curves may provide data that could be included in a multitrait index aimed at improving health and fertility and thereby reducing wasteage from the dairy herd for both welfare and environmental reasons.

Liveweight is potentially a useful management aid (Maltz et al., 1997), yet it is not routinely recorded in UK commercial dairy herds. Liveweight can be predicted from linear type measurements and subsequent genetic evaluations for LWT can be obtained with little loss in accuracy (Koenen and Groen, 1998). Given that BCS is recorded as part of the UK linear type assessment scheme for Holsteins, there is the opportunity to calculate sire breeding values for LWT and BCS using large amounts of national data.

The objectives of this study were: 1 ) to model LWT predicted from type traits and condition score measured in the field to obtain daily breeding values for sires; 2) to combine those daily estimates into an overall genetic energy balance profile; and 3) to compare genetic energy balance curves among sires. To do this we used random regression techniques and restricted maximum likelihood (REML) on data from first lactation cows participating in the national conformation assessment scheme.

\section{MATERIALS AND METHODS}

\section{Prediction of Liveweight}

To predict LWT from linear type traits, data for all first lactation cows were extracted from the database of Langhill records collected since 1990. This resulted in 766 records from 444 first lactation cows. The data included records of LWT collected weekly throughout lactation and linear type records collected up to three times per lactation. Cows at Langhill were assessed for conformation as part of the national type classification scheme run by the Breed Society responsible for black and white cows in the UK (HUK) but as part of another study the animals at Langhill were classified three times annually by the same organization. For this study the LWT record taken closest in time to each linear type inspection was used, producing between 1 and 3 records for each cow for inspections that occurred up to 12 mo after first calving. These data were analyzed using a stepwise regression procedure and the REML option in Genstat (Lawes Agricultural Trust, 1993).

$$
\begin{gathered}
y_{i k l m t}=y_{o i_{k}}+\operatorname{diet}_{l}+a a i_{m}+\Psi p c h+\operatorname{cow}_{i} \\
+\sum_{j=1}^{16} \beta_{j} x_{j}+e_{i \mathrm{klmt}}
\end{gathered}
$$

where $y_{i k l m t}=$ liveweight recorded on cow $i$ at day $t$ of lactation. For animal $i$, yoi $i_{\mathrm{k}}=$ the fixed effect of year of inspection, diet $_{l}=$ diet type (grazed grass or total mixed ration), $a a i_{m}=$ age at inspection (grouped into 3-mo classes), and the linear covariate $p c h=$ percentage North American Holstein genes. $\Psi$ is the regression coefficient of LWT on percentage of North American Holstein genes. $\beta_{j}$ are the regressions of LWT on the $j$ th linear type trait, $x_{j}$, and $\mathrm{e}_{\mathrm{iklmt}}$ is an error term. The cow was included in the model as a random effect since there were repeated observations on each cow.

\section{National Linear Type Data and Condition Score}

In the national conformation assessment scheme, information on 16 linear type traits and a number of other traits including BCS are scored on a 1 to 9 scale (Brotherstone et al., 1990). Participation in the overall scheme is voluntary although once a farm is committed, every heifer on the farm at the time of the visit must be inspected. Body condition score has been included in the scheme since August 1996, based on the scoring system of Lowman et al. (1976) but adapted to be scored on a 1 to 9 scale, where 1 is the lowest level of fatness and 9 is the highest level of fatness. Data for all heifers scored since August 1996 up to March 2001 were extracted from the HUK database. This produced 240,232 records. Scores for each trait were scaled by the ratio of the individual field officer standard deviation to the mean standard deviation for all field officers, in order to standardize the range of scores for all field officers (Brotherstone et al., 1990). After records were removed for animals inspected at day 0 or after day 305 of lactation, and from sire progeny groups of less than 10 , there remained 58,784 records on daughters of 1240 young sires with first crop daughters and 10 proven sires. Proven sires were included in the analysis in order to improve genetic connections within the data but these sires did not contribute to the between-sire variance component. For each of the cows in the final dataset, LWT was predicted using equation [1].

Genetic and environmental variance components were estimated using a random regression sire model 
Table 1. Number of records in each of the 10 residual error classes and the corresponding error variances for body condition score (BCS $\left(\right.$ units $\left.\left.^{2}\right)\right)$ and liveweight $\left(\mathrm{LWT}\left(\mathrm{kg}^{2}\right)\right)$.

\begin{tabular}{llll}
\hline & & \multicolumn{2}{c}{ Residual Error } \\
\cline { 3 - 4 } $\begin{array}{l}\text { Days of } \\
\text { Lactation }\end{array}$ & Number & BCS & LWT \\
\hline $1-15$ & 1053 & 1.64 & 765.8 \\
$16-29$ & 2723 & 1.66 & 633.1 \\
$30-59$ & 7829 & 1.64 & 589.0 \\
$60-89$ & 8621 & 1.64 & 568.3 \\
$90-119$ & 8336 & 1.67 & 562.9 \\
$120-149$ & 7943 & 1.77 & 610.0 \\
$150-179$ & 7112 & 1.83 & 628.7 \\
$180-209$ & 6162 & 1.77 & 602.2 \\
$210-239$ & 4851 & 1.84 & 664.7 \\
$240-305$ & 4154 & 1.76 & 655.0 \\
\hline
\end{tabular}

with the ASREML statistical package (Gilmour et al., 1998). The random regression model fitted in this study was:

$$
\begin{gathered}
y_{i j k t}=h v_{k}+\gamma_{1} a a c+\gamma_{2} p c h+\sum_{m=0}^{f-1} \beta_{m} P_{m}(t) \\
+\sum_{m=0}^{k-1} \alpha_{j m} P_{m}(t)+\varepsilon_{i j k t}
\end{gathered}
$$

where $y_{i j k t}$ is predicted LWT or BCS for daughters $i$ of sire $j$ in herd-visit $k$ at day $t$ of lactation. For daughter $i$ of sire $j, h v_{k}=$ herd-date-of-visit interaction (a herd may be visited twice a year), pch = percentage North American Holstein genes (linear) and $a a c=$ age at calving in months (linear and quadratic). $\gamma_{1}$ and $\gamma_{2}$ are the regression coefficients for age at calving and proportion North American Holstein genes respectively. $\beta_{m}$ are the fixed regression coefficients, $\alpha_{j m}$ are the additive genetic random regression coefficients for sire $j$ and $\varepsilon_{\mathrm{ijkt}}$ is the error associated with day $t$ of lactation. $P_{m}(t)$ is the $m$ th legendre polynomial evaluated at day $t$ of lactation and the parameters $f$ and $k$ are the order of the fixed and random polynomials, respectively. Legendre polynomials were used because they are easy to manipulate, have good convergence properties and, being orthogonal polynomials, correlations between coefficients are lower than between the coefficients of ordinary polynomials (Draper and Smith, 1998). Different residual errors were associated with observations over time and, based on preliminary analyses, residual error classes were defined as days of lactation as shown in Table 1. Within classes, residual errors were assumed to be homogeneous and between classes, residual covariances were assumed to be zero.

Based on previous genetic analyses of data from an experimental herd (Coffey et al., 2001), fixed regressions, which model the general shape of the curve and are common to all animals, were fitted for both traits as polynomials of order five. Second, third and fourth order polynomials were used to model the additive genetic effect and the goodness of fit was compared using a likelihood ratio test based on the $\chi^{2}$ distribution with the number of degrees of freedom equal to the difference in the number of variance components to be estimated.

Sire PTA obtained from the analysis were used to calculate daily values for each trait on the phenotypic scale for all sires in the dataset, for all traits for $d$ of lactation 1 to 305. Energy balance was derived using predicted body protein and lipid changes after converting all measures to energy equivalents using the effective energy system of Emmans (1994) with additional terms for the major organic components of milk. Details of the formulas used to convert to effective energy equivalents are given by Coffey et al. (2001).

The formula used to predict body lipid content from BCS is based on empty body weight (liveweight minus gut fill and weight of conceptus). The effects of pregnancy on the prediction of body lipid content were accounted for by modelling conceptus weight (ConW; fetus plus placenta plus fluid) at day $p$ after conception using the formula from Bruce et al. (1984) which assumes a calf birth weight of $40 \mathrm{~kg}$.

$$
\log _{10} \operatorname{Con} W=2.932-3.347 e^{-0.00406 \cdot p}
$$

The daily predicted weight of the conceptus was subtracted from LWT to ensure body lipid estimation was not biased upwards by the presence (weight) of conceptus. All sires were assumed to have average daughter fertility and the average daughter to be pregnant at $110 \mathrm{~d}$ of lactation. This expected day of conception corresponds to the average calving interval of around 390 $\mathrm{d}$ in the UK and ConW was modeled from day 110 of lactation. The effects of pregnancy and gut fill were assumed to be the same for all animals.

Dry matter intake (DMI) was predicted from the formula taken from NRC (1987)

$$
D M I_{i}=11.21+(0.11 \cdot t)-\left(0.0003 \cdot t^{2}\right)
$$

and was subsequently used to calculate gut fill (GF) for animal $i$ on day $t$ of lactation using the formula from Coffey et al. (2001)

$$
G F_{i}=\mathrm{DMI}_{\mathrm{i}} \cdot(11-(7 \cdot \mathrm{MEC} / 15))
$$

where MEC is the metabolizable energy content of the feed. A value of 11.82 was derived from the mean of all total mixed ration fed at Langhill for the last 10 years and was assumed to be indicative of the average MEC of dairy cattle feed available to a cow over one year. 


\section{RESULTS}

The following model for predicting LWT was chosen based on the significance of the partial regression coefficients:

$L W T=558.43+a a i+(-0.7022 \cdot p c h)+(-7.247 \cdot A n g)+$ $(8.505 \cdot C W)+(5.548 \cdot B D)+(8.529 \cdot S t a)+$ diet

where $a a i$ was $0.0,21.7,34.5,44.7,69.2$, or 68.7 for age at inspection in months of 23 to 25,26 to 28,29 to 31,32 to 34,35 to 37 , and $>37$, respectively. pch is percentage North American Holstein genes, Ang is angularity, $C W$ is chest width, $B D$ is body depth and Sta is stature. Data used to derive this formula were collected between 1990 and 2001. To generalize the formula so that it can be used with this period an average year of inspection solution has been included in the constant term. The variable diet had a value of 0 when the animals were eating grass and 34.79 when housed inside eating conserved forage. For national data it was assumed that animals were outside between mo 4 and 9 (April to September).

The correlation between actual and predicted LWT was 0.92 , i.e., $85 \%$ of the variance in LWT was accounted for using the prediction formula. Predictions of LWT in the national population may be inferior in accuracy if the Langhill data used to derive the prediction formula are not representative of the general population. It would be useful to obtain additional data from other herds where LWT and linear type data were available to test the formula on cows not contributing data to the formula. Since these data were not available the correlation coefficient quoted is an upper limit.

For BCS, a significant improvement in fit resulted when the order of the polynomial for the random curve was increased from 3 to 4 , indicating that a polynomial of order 4 (cubic) was better able to model the data than a quadratic polynomial. For LWT, there were convergence problems using order 4 for the random curve so order 3 was used.

Residual error classes (Table 1) were based on earlier work (Coffey et al., 2002) and preliminary analysis of these data. Ten classes were defined ranging in size from 1053 records (d 1 to 15 ) to 8621 records (d 60 to 89). Values of error variance found in this analysis are larger than those obtained from a genetic analysis of experimental data (Coffey et al., 2001), but the data used here were taken from national records that are likely to be more variable than those from an experimental farm. Values of error variance for LWT are similar to those reported by Koenen and Groen (1998) and for BCS are similar to those reported by Koenen et al. (2001).

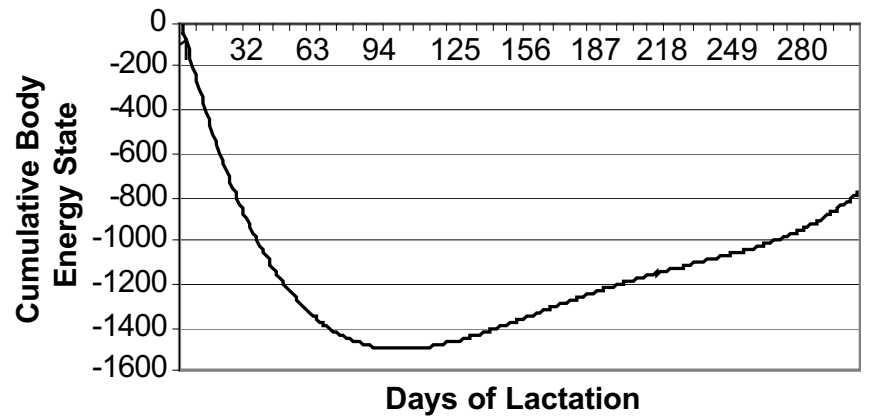

Figure 1. Average cumulative body energy state (MJ) for each day of lactation for all sires.

The daily average sire solutions for body energy loss, relative to the start of lactation (cumulative body energy state), for LWT and BCS are given in Figures 1 and 2. For all sires, the overall mean maximum daughter body energy loss was $1499 \mathrm{MJ}(\mathrm{SD}=144 \mathrm{MJ})$ and occurred at d 99 ( $\mathrm{SD}=12.8 \mathrm{~d}$ ) of lactation, whereas the mean total daughter body energy loss at $d 305$ of lactation was $779 \mathrm{MJ}(\mathrm{SD}=224 \mathrm{MJ})$.

Cumulative body energy state is shown in Figure 3 for the two highest and two lowest sires in the dataset ranked on profit index (PIN), an index used in the UK based on milk, fat and protein weighted by their relative economic values. Predicted Transmitting Ability values were taken from the February 2002 Interbull file. These four sires had 23, 91, 11 and 23 daughters in the linear type dataset, respectively. These curves show that sires differ in the way their daughters lose and regain body energy throughout lactation. For the same sires, breeding values for LWT and BCS are given in Figures 4 and 5 , respectively.

Genetic variances and heritabilities for LWT and BCS on each day of lactation are given in Figures 6

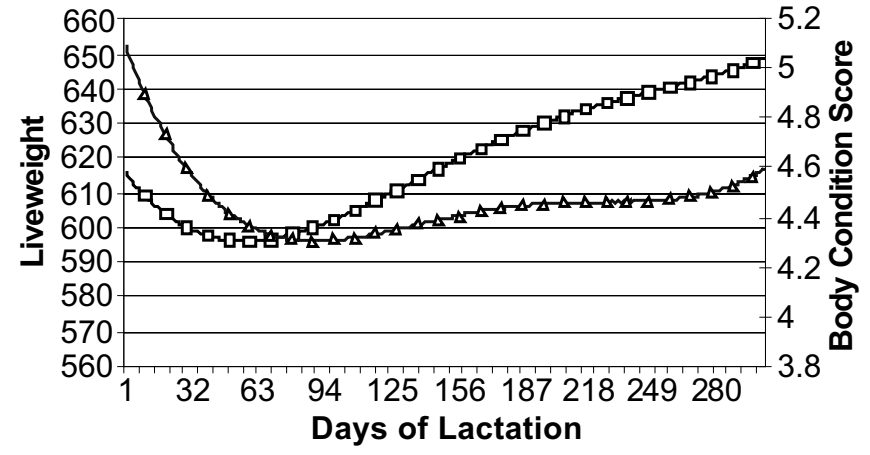

Figure 2. Average liveweight $(\mathrm{kg}, \square)$ and body condition score (units, $\triangle$ ) for each day of lactation for all sires. 


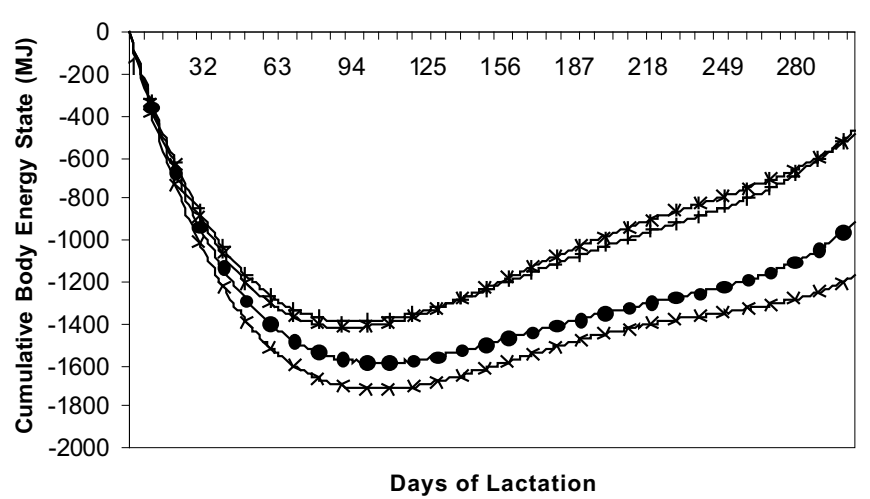

Figure 3. Cumulative body energy state $(\mathrm{MJ})$ for the top $(X$ and *) and bottom (+ and 0 ) two sires ranked on profit index (PIN).

and 7, respectively. The use of residual error classes, rather than modeling the residual error with a continuous function, creates the stepwise change in heritabilities. This is more pronounced for LWT than BCS.

For BCS, genetic correlations declined from near unity between adjacent days at the start of lactation to around 0.4 between $d 1$ and 110 rising to 0.60 between $\mathrm{d} 1$ and 201 before declining to 0.20 between $\mathrm{d} 1$ and 305 (Figure 8), whereas for LWT the correlations between d 1 and succeeding days reached a minimum at around d 180 and remained low thereafter (Figure 9). In a previous analysis of the data on the Langhill herd, Coffey et al. (2001) found a similar pattern of correlations for BCS and LWT. They estimated that the genetic correlation for BCS declined from near unity between adjacent observations to 0.17 between $\mathrm{d} 7$ and 247. For LWT they estimated a minimum correlation of 0.77 between $\mathrm{d} 7$ and 180 .

\section{DISCUSSION}

The resumption of reproductive activity in dairy cows postpartum in most dairy cows occurs only after the

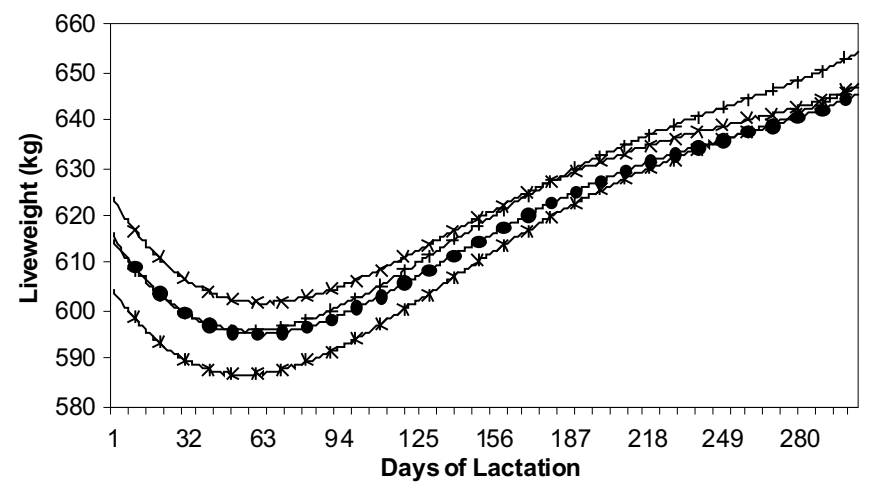

Figure 4. Liveweight $(\mathrm{kg})$ for the top $(X$ and $*)$ and bottom $(+$ and $\bullet$ ) two sires ranked on profit index (PIN).

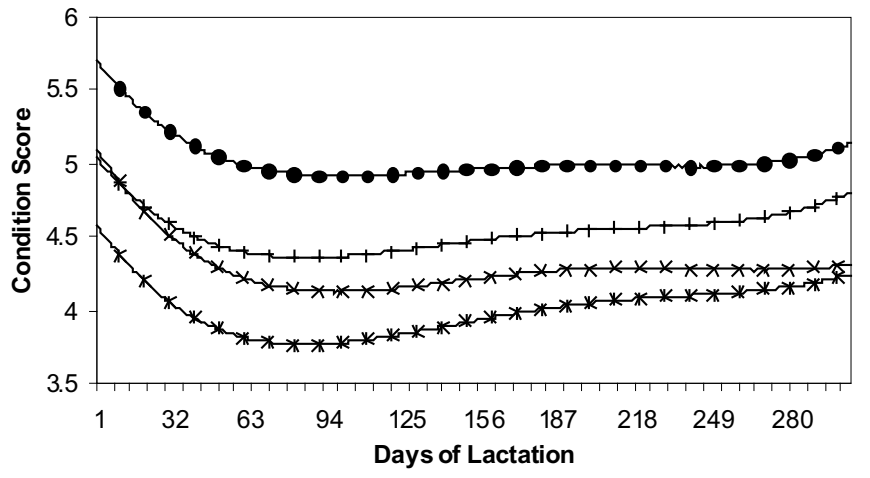

Figure 5. Body condition score for the top $(X$ and $*)$ and bottom $(+$ and -$)$ two sires ranked on profit index (PIN).

nadir of negative energy balance has been reached (Butler and Smith, 1989; De Vries et al., 1999; Veerkamp et al., 2000). This indicates that the rate of return to positive daily energy balance may be a useful indicator of resumption of reproductive activity and, by implication, a useful selection objective to improve fertility in dairy cattle. Over the lifetime of the animal, the replenishment of body lipid is cyclical (Coffey et al., 2002) and failure to replenish sufficient body lipid in one lactation may result in carry-over effects in subsequent lactations. Therefore, the rate of return to positive daily energy balance may also affect the total amount of body lipid replenished in one lactation that in turn may affect health and fertility traits in subsequent lactations.

Genetic variance for both traits used in this study rose abruptly towards the end of lactation. This had the effect of increasing the heritability in a similar fashion. At the minimum point of the trajectory, the heritability for LWT was about 0.30 and for BCS was about 0.25 , which is similar to estimates reported elsewhere (Jones et al., 1999; Veerkamp et al., 2000). However,

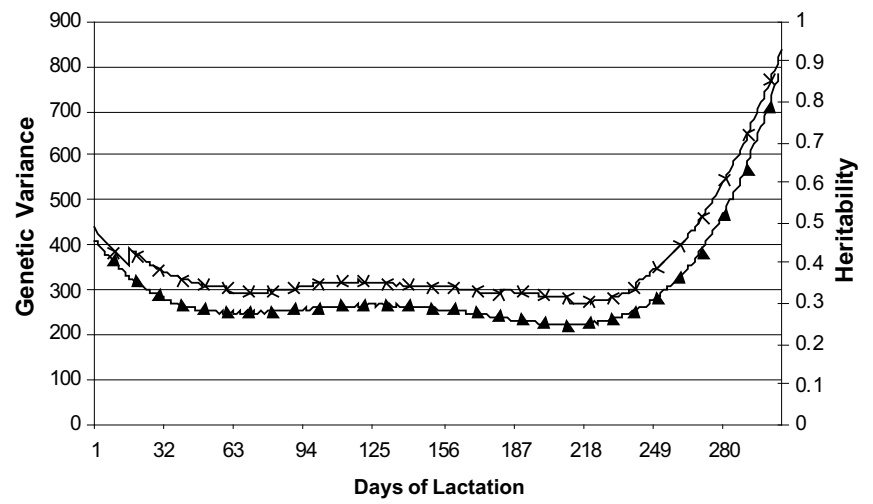

Figure 6. Genetic variance $(\boldsymbol{\Delta})$ and heritability $(X)$ of liveweight for all sires for each day of lactation. 


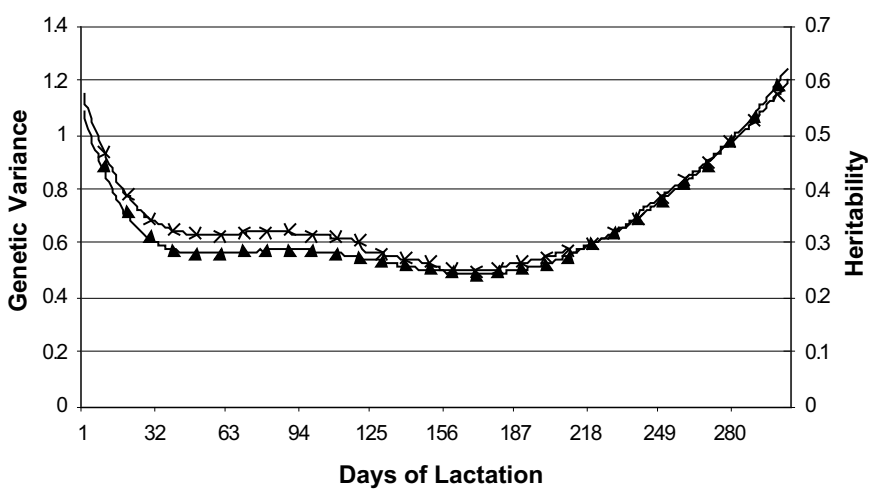

Figure 7. Genetic variance $(\boldsymbol{\Delta})$ and heritability $(X)$ of body condition score for all sires for each day of lactation.

the rise in genetic variance at both ends of the trajectory increased the heritability to unusually high values of around 0.90 for LWT and 0.60 for CS. An increase in genetic variance at the right extreme of the trajectory could be because pregnancy effects had not been fully accounted for in this analysis and at both extremes because there were limited data at these points (Pool et al., 2000). Conversely, Fischer and van der Werf (2002) found, using simulated data, that the numbers of records at the extremities had little effect on the variance. In the study reported here, conceptus weight in pregnancy was modeled to remove the additional predicted weight of the conceptus. There may be other effects not accounted for, that alter either the shape of the animal, and hence the linear type scores used to predict liveweight, or the assessment of BCS, for example, fluid retention.

The relationship between body size (or LWT) and profitability is not clear. Sieber et al. (1988) reported that, in the US, taller cows produced more milk than shorter cows but lighter cows produced more fat corrected milk than did heavier cows in their first and

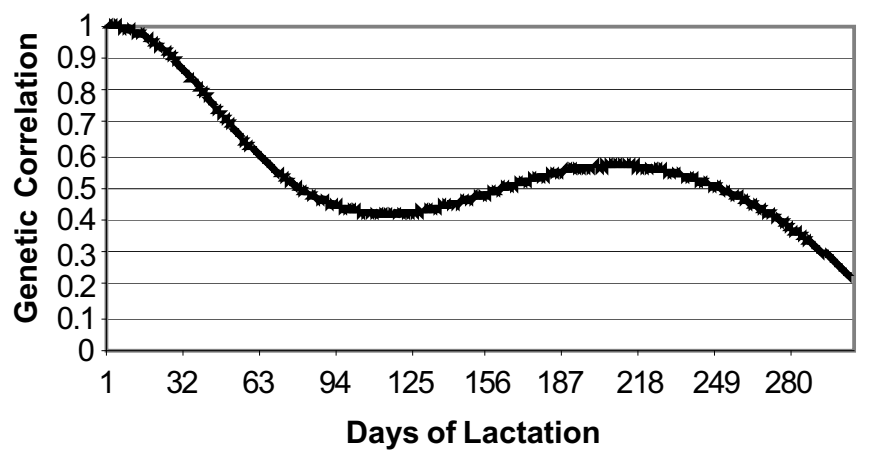

Figure 8. Genetic correlations of body condition score at d 1 for all sires with each succeeding day of lactation.

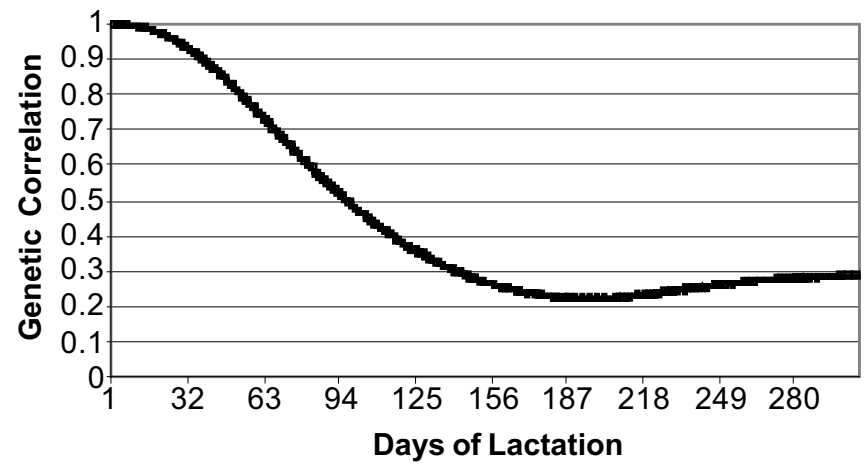

Figure 9. Genetic correlations of liveweight at d 1 with each succeeding day of lactation for all sires.

later lactations. There is conflicting evidence regarding the benefit of using LWT in a selection index since its economic value is uncertain. In New Zealand, Spelman and Garrick (1997) show that inclusion of a negative economic weight for LWT optimizes profitability in a multitrait index and is expected to lead to a genetic reduction in LWT of $0.19 \mathrm{~kg} / \mathrm{year}$ at a selection intensity of $1.95 \mathrm{SD}$. However, BCS is a measure that predicts the proportion of LWT (empty body weight) that is lipid, and reducing LWT at a fixed BCS will lead to a lower total amount of body lipid in the cow. Veerkamp (1998) concluded that the relationship between feed intake, LWT and efficiency is confounded by the relationship of yield and LWT with body tissue mobilization. The negative consequences of a reduction in body lipid content of cows at reduced LWT should be considered before incorporating size or LWT into a multitrait index.

Mean maximum body energy loss for progeny of all sires reported in this study (1499 MJ) occurred at d 99 of lactation and is similar to but, as expected, slightly higher than that reported by Tamminga et al. (1997) who found a total body energy loss of $1284 \mathrm{MJ}$ up to d 56 of lactation. In study reported here, the profiles of body energy loss indicate that daughters of the majority of sires lost most body energy before $\mathrm{d} 150$ and then recovered body energy, whereas a few continued to lose body energy through to the end of lactation. Current genetic evaluations for production do not account for energy contributions from body tissue mobilization, therefore some sires with high merit for production may have daughters with unacceptable body tissue mobilization profiles, leading to higher costs associated with poorer health and fertility. A method of accounting for this cost could be to correct yield for body tissue mobilization. In the energy system used in this study (Emmans, 1984), production of $1 \mathrm{~kg}$ milk (at $4.2 \%$ fat, $3.4 \%$ protein and $4 \%$ lactose) requires approximately $4.2 \mathrm{MJ}$ effective energy. The cumulative body energy loss at $d$ 


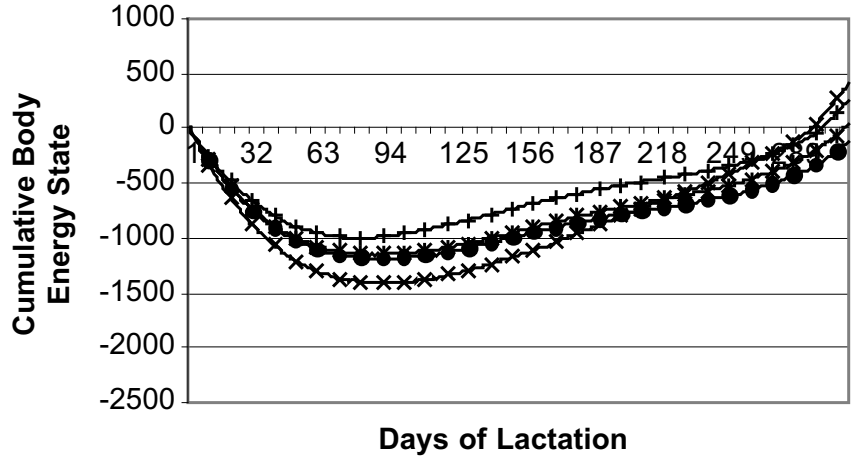

Figure 10. Cumulative body energy state (MJ) for the four sires that increased most in rank when milk accounted for by body energy was deducted from their milk PTA.

305 of lactation was converted to the effective energy equivalent in $\mathrm{kg}$ milk for each sire. Using this method, the mean amount of milk accounted for by body energy loss was $189 \mathrm{~kg}$ milk, which is similar to the value of $324 \mathrm{~kg}$ milk quoted by Tamminga et al. (1997). Deducting the body energy equivalent of $\mathrm{kg}$ milk from the breeding value for milk for each sire resulted in a correlation of 0.98 between the ranking of sires before and after adjustment. However, some sires changed rank by large amounts, the largest being +355 positions . The four sires that moved up the ranking by the most places as a result of contributing body tissue to milk production when ranked on the adjusted milk PTA are given in Figure 10. These four sires had 3211, 3380, 44 , and 125 daughters, respectively. The four sires that decreased the most in the rankings are given in Figure 11 and these sires had 60,20,28, and 21 daughters, respectively. These groups of sires have clear differences in the profiles of body energy loss and gain of their daughters with those in Figure 10 actually gaining

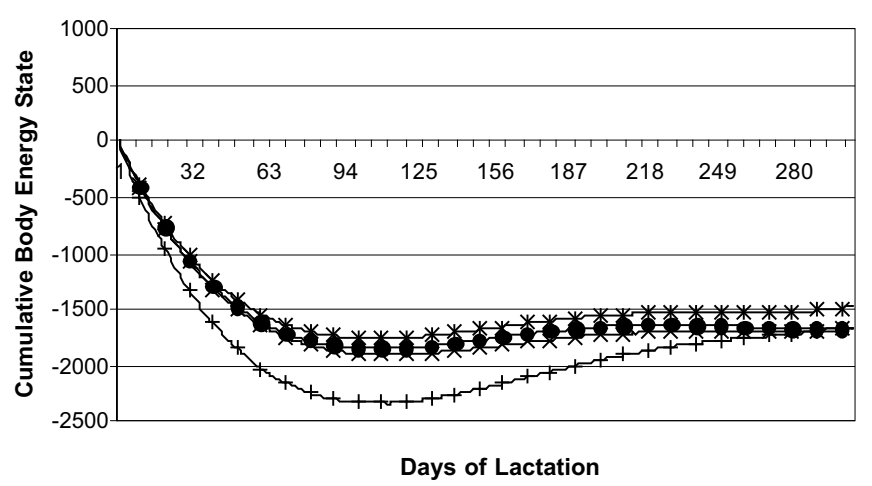

Figure 11. Cumulative body energy state (MJ) for the four sires that decreased most in rank when milk accounted for by body energy was deducted from their milk PTA. body energy at the end of lactation. Pryce et al. (2001) suggested that using BCS at some stages of lactation in an index could help alleviate the unfavorable effect of selection for yield on fertility. Further work is required to determine the most useful and informative parameters of the BCS curve over multiple lactations.

The strategic use of body tissue over the lifetime of the cow may be more important when assessing the cow's overall utility including costs rather than just its production, particularly since measures of utility currently used are often expressed only on a single lactation basis. The effect of a selection policy that emphasizes milk yield and does not include change in body energy content on traits such as longevity, health, and welfare over the lifetime of the cow has yet to be fully studied. The effect of cyclical body tissue loss and repletion is not only seen on production but is, arguably, more important to the welfare of the cow, the consumer's view of milk production systems, the cow's potential survival and the effect of dairy farming on the environment through disposal of cull animals. Future selection indices could include indicators of body energy content as predictors of health and survival. Also, genetic evaluations for milk production in each lactation could be adjusted for body energy used in that same lactation.

\section{CONCLUSIONS}

Breeding values for energy balance can be calculated from single observations of BCS and linear type traits, data that can routinely be collected in national conformation assessment schemes. Random regression techniques of analysis provide a time-oriented dimension to genetic evaluations that has a potentially valuable role in future genetic improvement programs for dairy cattle. Correcting sire milk yield PTA's for the cumulative body lipid mobilization of daughters may provide a broader measure of utility of a sires' worth when also considering health, fertility, and survival.

\section{ACKNOWLEDGMENTS}

We are grateful to the staff at Langhill Farm for diligently recording data used in this study over a long period. Arthur Gilmour is acknowledged for his help with ASREML used in the analysis and John Woolliams is thanked for making an eminently sensible suggestion. SAC receives financial support from the Scottish Executive Environment and Rural Affairs Department.

\section{REFERENCES}

Brotherstone, S., M. McManus, and W. G. Hill. 1990. Estimation of genetic parameters for linear type traits in Holstein Friesian dairy cattle. Anim. Prod. 59:183-187. 
Bruce, J. M., P. J. Broadbent, and J. H. Topps. 1984. A model of the energy system of lactating and pregnant cows. Anim. Prod. 38:351-362.

Butler, R. W., and R. D. Smith. 1989. Interrelationships between energy balance and postpartum reproductive function in dairy cattle. J. Dairy Sci. 72:767-783.

Coffey, M. P., G. E. Emmans, and S. Brotherstone. 2001. Genetic evaluation of dairy bulls for energy balance traits using random regression. Anim. Sci. 73:29-40.

Coffey, M. P., G. Simm, and S. Brotherstone. 2002. Energy balance for the first three lactations of dairy cows estimated using energy balance. J. Dairy Sci. 85:2669-2678.

Collard, B. L., P. J. Boettcher, J. C. M. Dekkers, D. Peticlerc, and L. R. Schaeffer. 2000. Relationships between energy balance and health traits of dairy cattle in early lactation. J. Dairy Sci. 83:2683-2690.

De Vries, M. J., S.Van Der Beek, L. M. T. E. Kaal-Lansbergen, W. Ouweltjes, and J. B. M. Wilmink. 1999. Modeling of energy balance in early lactation and the effect of energy deficits in early lactation on first detected estrus postpartum in dairy cows. J. Dairy Sci. 82:1927-1934.

De Vries, M. J., and R. F. Veerkamp. 2000. Energy balance of dairy cattle in relation to milk production variables and fertility. J. Dairy Sci. 83:62-69.

Draper, N. R., and H. Smith. Applied Regression Analysis. Chapter 22. p 461-467. Published by John Wiley \& Sons Inc. 1998 (Third edition).

Emmans, G.C. 1994. Effective energy: A concept of energy utilisation applied across species. Br. J. Nutr. 71:801-821.

Fischer, T. M., and J. H. J. van der Werf. 2002. Effect of data structure on the estimation of genetic parameters using random regression. 7th World Congress on Genetics Applied to Livestock Production, Montpellier, France. Communication No. 17-08.

Fox, D. G., M. E. Van Amburgh, and T. P. Tylutki. 1999. Predicting requirements for growth, maturity and body reserves in dairy cattle. J. Dairy Sci. 82:1968-1977.

Gilmour, A. R., B. R. Cullis, S. J. Welham, and R. Thompson. 1998. ASREML User's Manual, October, 1998. New South Wales Agriculture, Orange Agricultural Institute, Orange, NSW, Australia.

Jones, H. E., I. M. S. White, and S. Brotherstone. 1999. Genetic evaluation of Holstein Friesian sires for daughter condition score changes using a random regression model. Anim. Sci. 68:467-476.

Koenen, E. P. C., and A. F. Groen. 1998. Genetic evaluation of body weight of lactating holstein heifers using body measurements and conformation traits. J. Dairy Sci. 81:1709-1713.

Koenen, E. P. C., R. F. Veerkamp, P. Dobbelaar, and G. De Jong. 2001. Genetic analysis of body condition score of lactating Dutch Holstein and Red and White heifers. J. Dairy Sci. 84:1265-1270.
Lawes Agricultural Trust. 1990. Genstat 5 Reference Manual. Clarendon Press, Oxford, UK.

Lowman, B. G., N. Scott, and S. Somerville. 1976. Condition Scoring of Cattle. Bulletin No. 6. East of Scotland College of Agriculture, Edinburgh, Scotland.

Maltz, E., S. Devir, J. H. M. Metz, and H. Hogeveen. 1997. The body weight of the dairy cow I. Introductory study into body weight changes in dairy cows as a management aid. Livest. Prod. Sci. 48:175-186.

National Research Council. 1987. Predicting feed intake of food producing animals. P 48.

Pond, C. M., and E. A. Newsholme. 1999. Coping with metabolic stress in wild and domesticated animals. British Society of Animal Science Occasional Publication 24. 9-20.

Pool, M. H., L. L. G. Janss, and T. H. E. Meuwissen. 2000. Genetic parameters of legendre polynomials for first parity lactation curves. J. Dairy Sci. 83:2640-2649.

Pryce, J. E., B. L. Nielsen, R. F. Veerkamp, and G. Simm. 1999. Genotype and feeding system effects and interactions for health and fertility in dairy cattle. Livest. Prod. Sci. 57:193-201.

Pryce, J. E., M. P. Coffey, and G. Simm. 2001. The relationship between body condition score and reproductive performance. J. Dairy Sci. 84:1508-1515.

Sieber, M., A. E. Freeman, and D. H. Kelley. 1988. Relationships between body measurements, body weight and productivity in Holstein dairy cows. J. Dairy Sci. 71:3437-3445.

Spelman, R. J., and D. J. Garrick. 1997. Effect of live weight and differing economic values on responses to selection for milk, fat, protein, volume and live weight. J. Dairy Sci. 80:2557-2562.

Tamminga, S., P. A. Luteijn, and R. G. M. Meijer. 1997. Changes in composition and energy content of liveweight loss in dairy cows with time after parturition. Livest. Prod. Sci. 52:31-38.

Veerkamp, R. F. 1998. Selection for economic efficiency of dairy cattle using information on live weight and feed intake: A review. J. Dairy Sci. 81:1109-1119.

Veerkamp, R. F., and S. Brotherstone. 1997. Genetic correlations between linear type traits, food intake, live weight and condition score in Holstein Friesian dairy cattle. Anim. Sci. 64:385-392.

Veerkamp, R. F., J. K. Oldenbroek, H. J. Van der Gaast, and J. H. J. Van der Werf. 2000. Genetic correlation between days until start of luteal activity and milk yield, energy balance and live weights. J. Dairy Sci. 83:577-583.

Veerkamp, R. F., E. P. C. Koenen, and G. De Jong. 2001. Genetic correlations among body condition score, yield and fertility in first parity cows estimated by random regression models. J. Dairy Sci. 84:2327-2335.

Veerkamp, R. F., and R. Thompson. 1999. A covariance function for feed intake, live weight and milk yield estimated using a random regression model. J. Dairy Sci. 82:1565-1573. 